GRASAS Y ACEITES 70 (1)

January-March 2019, e285

ISSN-L: 0017-3495

https://doi.org/10.3989/gya.0235181

\title{
Sex and seasonal variation in proximate composition and fatty acid profile of Scomber scombrus (L. 1758) fillets from the Middle East Coast of Tunisia
}

\author{
S. El Oudiani ${ }^{\mathrm{a}}$, I. Chetoui ${ }^{\mathrm{b}}$, C. Darej ${ }^{\mathrm{a}}$ and N. Moujahed ${ }^{\mathrm{a}}$ \\ ${ }^{a}$ National Institute of Agricultural Sciences of Tunisia, University of Carthage, 43 Av. Charles Nicolle 1082 Tunis Mahrajen, Tunisia, \\ Laboratory of animal and food resources. \\ ${ }^{b}$ University of Tunis El Manar, Faculty of Sciences of Tunis, Biology Department, Research Unit of physiology and aquatic \\ environment, 2092, Tunis, Tunisia. \\ Corresponding author: salma.inat@yahoo.fr
}

Submitted: 01 March 2018; Accepted: 10 July 2018

\begin{abstract}
SUMMARY: This study investigates the impact of season and sex variations on the total lipid contents and fatty acid composition of Scomber scombrus fillets from the Middle East Coast of Tunisia in order to dertermine the most favorable periods for consumption, and to see if the nutritional quality of the meat depends on the sex of the animal. The effect of fishing season induced significant changes in the lipid profile, and the highest values for total lipids were obtained in the spring for females with $13.2 \%$ and for males with $18.9 \%$. The highest values for proteins were obtained in the summer for females with $22.0 \%$ and for males with $21.8 \%$. Protein content variations were not significant $(\mathrm{p}>0.05)$. The $n-3 / n-6$ ratio showed a significant level, indicating a tendency toward n-3 fatty acid accumulation in mackerel fillets mainly represented by DHA, whose values were high during the study period for both sexes, except in autumun, which is the period of mackerel gonad maturation, when DHA decreased significantly ( $\mathrm{p}<0.05$ ), reaching 23.2 and $34.0 \%$ for males and females, respectively. It was concluded that Scomber scombrus has high levels of proteins, lipids, and fatty acid contents mainly n-3 PUFA. DHA sex variations were not significant ( $p>0.05$ ). The Atherogenicity index (AI) and Thrombogenicity index (TI) were calculated. In our study the AI index was comprised between 0.3 and 0.6 for males and between 0.4 and 0.5 for females. The TI index values ranged from 0.6 to 0.8 for males, and was about 0.6 for females.
\end{abstract}

KEYWORDS: Fatty acids; Nutritional quality; Proximate composition; Scomber scombrus; Seasons; Sex

RESUMEN: Variación estacional y sexual en la composición y perfil de ácidos grasos en filetes de caballa, Scomber scombrus (L. 1758) de la costa este tunecina. Este estudio investiga el impacto de las variaciones estacionales y sexuales sobre el contenido total de lípidos y la composición de ácidos grasos de filetes de caballa, Scomber scombrus, de la Costa Este Tunecina, con objeto de determinar los períodos más favorables para su consumo y para ver si la calidad nutricional de la carne depende del sexo del animal. Los efectos de la temporada de pesca indujeron cambios significativos en el perfil de lípidos, así, los valores más altos de lípidos totales se obtuvieron en primavera para las hembras, $13,2 \%$ y para los machos, $18,9 \%$. Los valores más altos de proteína se obtuvieron en verano para las hembras, $22,0 \%$ y para los machos $21,8 \%$. Las variaciones en el contenido de proteínas no fueron significativas $(\mathrm{p}<0.05)$. La relación $\mathrm{n}-3 / \mathrm{n}-6$ mostró un nivel significativo que indica una tendencia a la acumulación de ácidos grasos n-3 en filetes de caballa representados principalmente por DHA, cuyos valores fueron altos durante el período de estudio para ambos sexos, excepto en el otoño donde el DHA disminuyó significativamente ( $\mathrm{p}<0.05$ ), alcanzando el $23,2 \%$ y el $34,0 \%$ para machos y hembras respectivamente; período de maduración de las gónadas de la caballa. Se concluye que Scomber scombrus posee un alto contenido de proteínas, lípidos y ácidos grasos, principalmente AGPI n-3. La variación de sexo sobre el contenido de DHA no fue significativa $(\mathrm{p}<0.05)$. Se calcularon el índice de aterogenicidad (AI) y el índice de trombogenicidad (TI). En este estudio, el índice AI estaba comprendido entre 0,3 y 0,6 para los machos y entre 0,4 y 0,5 para las hembras. Los valores del índice TI oscilaron entre 0,6 y 0,8 para machos y fue de aproximadamente 0,6 para las hembras.

PALABRAS CLAVE: Ácidos grasos; Calidad nutricional; Composición próxima; Estaciones; Scomber scombrus; Sexo ORCID ID: El Oudiani S https://orcid.org/0000-0002-2762-3967, Chetoui I https://orcid.org/0000-0002-2259-5397, Darej C https://orcid.org/0000-0002-8147-7630, Moujahed N https://orcid.org/0000-0003-0437-1696

Citation/Cómo citar este artículo: El Oudiani S, Chetoui I, Darej C, Moujahed N. 2019. Sex and seasonal variation in proximate composition and fatty acid profiles in Scomber scombrus (L. 1758) fillets from the Middle East Coast of Tunisia. Grasas Aceites 70 (1), e285. https://doi.org/10.3989/gya.0235181

Copyright: (C2019 CSIC. This is an open-access article distributed under the terms of the Creative Commons Attribution 4.0 International (CC BY 4.0) License.

ABREVIATION: Docosahexaenoic acid (DHA), Eicosapentaenoic acid (EPA), Saturated fatty acids (SFA) Monounsaturated fatty acids (MUFA), Polyunsaturated fatty acids (PUFA). 


\section{INTRODUCTION}

The blue species Scomber scombrus is an abundant pelagic species caught in different regions of Tunisia. This mackerel's catch represents about 15\% of total pelagic fisheries. According to the General Direction of Fishing and Aquaculture in Tunisia (DGPA), the production of pelagic fisheries including mackerels fluctuates from year to year, and from port to port with a general decreasing tendency which reached 44,208 tons in 2010. The maximum production of mackerel in the port of Teboulba was about 3072 tons in 2005, with summer representing the highest catch season. Seafood products are the most beneficial to human health, and their consumption is recommended by nutritionists at least once a week, especially blueback fish.

Apart from their easy digestibility and high levels of protein and lipid contents, fish also are rich in vitamins and different minerals (Dan-Kishiya, 2013). The lipid characteristics of fish include a low cholesterol level (Hunter et al., 2000) and $\omega 3$ polyunsaturated fatty acids, mainly eicosapentaenoic (C20:5n-3, EPA) and docosahexaenoic (C22:6n-3, DHA) fatty acids, which play an important role in the prevention of some diseases, such as cardiovascular, rheumatoid, arthritis, gastroenterologic and dermatologic pathologies (Simopoulos, 2002), along with several types of cancer, with anti-thrombotic effects which reduce cholesterolemia. In addition, a diet which is rich in these valuable nutrients reduces levels of triglycerides in plasma and the very low-density lipoprotein proportion (VLDL) (Harris, 1989).

Belonging to the Scombridae family, Scomber scombrus is a blueback fish species which is rich in polyunsaturated fatty acids. It is characterized by a high percentage of DHA and EPA (RubioRodríguez et al., 2010). According to Paulina et al., (2016) the Atlantic mackerel caught during the summers of 2012 and 2013 from different sites of the Icelandic fishing area revealed a seasonal variation in its lipid contents and rancidity development.

The chemical composition of fish fillets is generally unstable, and may vary with season, water salinity and temperature, size, sex, fish age, maturity, the characteristics of the specific sea area, food availability and diet composition (Garrido et al., 2008).

In order to valorize the quality of our fish flesh, some nutritional indexes were calculated. As signaled by nutritionists, the $n-3 / n-6$ ratio has been suggested as a good standard to compare the nutritional value of oils present in fish meat; a n-3/n-6 ratio of $1: 1$, or $1: 1.5$ can contribute to a healthy diet for humans (Osman et al., 2001).

Two other nutritional quality indexes, the atherogenicity index (AI) and thrombogenicity index (TI) were considered as healthy lipid indices and were evaluated from the fatty acid composition data (Ulbricht et al., 1991).
This study evaluates with the effect of seasons and sex on the proximate and fatty acid compositions of the fillets of Scomber scombrus, caught from the Middle East Coast of Tunisia, in order to determine the most favorable periods for consumption and to determine whether the nutritional quality of the meat depends on the sex of the animal.

\section{MATERIALS AND METHODS}

\subsection{Sampling strategy}

Mackerel samples were collected monthly from the fishing off Teboulba, located on the Middle East Coast of Tunisia, during the period extending from June, 2010 to May, 2011. At landing, samples were transferred directly to the laboratory, where somatometric measurements were taken (total lenght (TL), total weight (TW)) and the fish were beheaded, washed, filleted, packed and then frozen at $\left(-20^{\circ} \mathrm{C}\right)$. The sample storage period before analysis did not exceed two days. During the study period, the analyses were based on samples with comparable body size and this was done monthly with parity between males and females (Table 1). In the present work, the analyzed muscle fragment cams from the left side of the animal and corresponded to the latero-dorsal part as indicated in Figure 1.

\subsection{Proximate analysis}

Crude protein $(\mathrm{N} \times 6.25)$ was analyzed by the Kjeldahl method AOAC (1990). The moisture content was determined by oven-drying for $4 \mathrm{~h}$ at $105^{\circ} \mathrm{C}$ following the AOAC (1990) method, until a constant weight was reached. Lipid extraction was carried out using the Soxhlet method (AOCS, Ba 3-38) in triplicate, with $5 \mathrm{~g}$ of dry weight flesh powder with $200 \mathrm{ml}$ of petroleum ether for $6 \mathrm{~h}$. The extracted lipids were evaporated under vacuum at $65{ }^{\circ} \mathrm{C}$ in a rotary evaporator, and then placed in an oven at $45^{\circ} \mathrm{C}$ for $1 \mathrm{~h}$, before being transferred into desiccators and weighed again. The muscle fragment used for the analysis came from the left side of the fish and corresponded to the central part.

\subsection{Fatty acids analysis}

Methyl ester preparation was done by a direct transesterification according to the Mosers (1991) method. Mackerel lipid extract was vortexed with $1 \mathrm{ml}$ (methanol/methylene chloride at 3:1); an internal standard (Heptadecanoic acid, C17:0), which did not exist in our sample and servied to quantify fatty acids, was added to the mixture. Then $200 \mu$ lof acetylchloride were added and vortexed and the mixture was incubated in an oven at $75{ }^{\circ} \mathrm{C}$ for one hour. After cooling for $15 \mathrm{~min}$ at 
TABLE 1. Number and body size of monthly Mackerel sampels.

\begin{tabular}{|c|c|c|c|c|}
\hline Months & Sexes & $\begin{array}{c}\text { Numbers } \\
(\mathbf{N})\end{array}$ & $\begin{array}{l}\text { Mean Total } \\
\text { lenght (Lt) }\end{array}$ & $\begin{array}{l}\text { Mean Total } \\
\text { weight (Wt) }\end{array}$ \\
\hline \multirow[t]{2}{*}{ june-2010 } & Males & 3 & $23.03 \pm 0.92$ & $110.65 \pm 9.20$ \\
\hline & Females & 3 & $23.33 \pm 1.04$ & $116.19 \pm 15.87$ \\
\hline \multirow[t]{2}{*}{ july-2010 } & Males & 3 & $27.20 \pm 1.56$ & $170.48 \pm 26.10$ \\
\hline & Females & 3 & $26.93 \pm 1.37$ & $172.91 \pm 17.50$ \\
\hline \multirow[t]{2}{*}{ aug-2010 } & Males & 3 & $25.66 \pm 1.04$ & $151.00 \pm 23.73$ \\
\hline & Females & 3 & $26.33 \pm 2.34$ & $175.00 \pm 51.44$ \\
\hline \multirow{2}{*}{ sept-2010 } & Males & 3 & $25.17 \pm 2.65$ & $158.00 \pm 17.04$ \\
\hline & Females & 4 & $25.80 \pm 3.58$ & $174.80 \pm 15.21$ \\
\hline \multirow[t]{2}{*}{ oct-2010 } & Males & 3 & $24.63 \pm 2.00$ & $142.00 \pm 29.87$ \\
\hline & Females & 3 & $25.37 \pm 0.23$ & $158.50 \pm 6.60$ \\
\hline \multirow[t]{2}{*}{ nov-2010 } & Males & 3 & $16.97 \pm 0.25$ & $41.50 \pm 4.40$ \\
\hline & Females & 5 & $17.10 \pm 0.14$ & $41.00 \pm 4.00$ \\
\hline \multirow[t]{2}{*}{ dec-2010 } & Males & 3 & $26.10 \pm 1.31$ & $178.10 \pm 9.05$ \\
\hline & Females & 3 & $28.60 \pm 1.93$ & $229.60 \pm 13.80$ \\
\hline \multirow[t]{2}{*}{ jan-2011 } & Males & 3 & $24.06 \pm 1.00$ & $211.50 \pm 5.30$ \\
\hline & Females & 3 & $23.66 \pm 1.60$ & $118.70 \pm 6.00$ \\
\hline \multirow[t]{2}{*}{ feb-2011 } & Males & 3 & $29.00 \pm 1.73$ & $144.60 \pm 19.00$ \\
\hline & Females & 3 & $29.37 \pm 0.64$ & $162.32 \pm 5.40$ \\
\hline \multirow[t]{2}{*}{ mar-2011 } & Males & 3 & $24.26 \pm 0.46$ & $118.83 \pm 5.48$ \\
\hline & Females & 3 & $24.00 \pm 1.08$ & $104.22 \pm 15.03$ \\
\hline \multirow[t]{2}{*}{ abr-2011 } & Males & 3 & $22.66 \pm 0.10$ & $100.30 \pm 13.86$ \\
\hline & Females & 3 & $21.70 \pm 1.37$ & $86.20 \pm 16.88$ \\
\hline \multirow[t]{2}{*}{ may-2011 } & Males & 4 & $21.00 \pm 1.61$ & $75.30 \pm 23.00$ \\
\hline & Females & 6 & $21.10 \pm 1.70$ & $93.00 \pm 25.10$ \\
\hline
\end{tabular}

$\mathbf{N}$ : number of specimens (males and females) in each month, Lt: mean total length $(\mathrm{cm})$, WT: mean total weight $(\mathrm{g})$

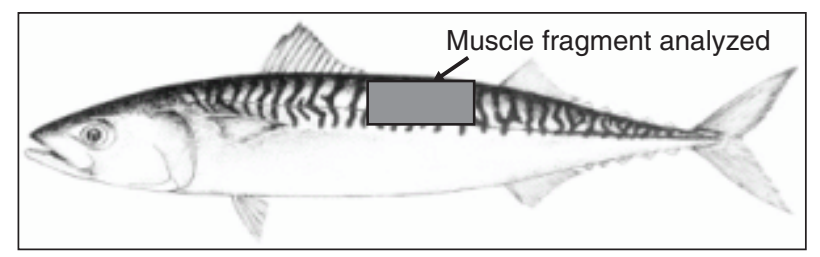

FIGURE 1. Scomber scombrus muscle fragment taken for analysis.

room temperature, $4 \mathrm{ml}$ of $(7 \%)$ potassium carbonate and hexane were added. The hexane layer was removed, and acetonitrile was added. Finally, the mixture was centrifuged and the hexane layer was dried under nitrogen. After that, $10 \mu \mathrm{l}$ of hexane were injected into the tube and shaken again. Then $1 \mu$ of the sample was extracted and used for the gas chromatography analysis.

Fatty acids were identified by gas chromatograph type HP series 6890 with a split/splitless injector and a flame ionization detector was used for the analysis. The device included a $30 \mathrm{~m}$ long HP Innowax capillary column with an internal diameter of $250 \mu \mathrm{m}$ and a $0.25 \mu \mathrm{m}$ film, the stationary polar phase of the column being polyethylene glycol. Comparison of the retention times of the fatty acids under study and those of standard fatty acids methyl esters (PUFA-3), allowed for identifying the different fatty acids contained in mackerel lipid extract.

\subsection{Nutritional quality indexes}

The atherogenicity index (AI) and thrombogenicity index (TI) were evaluated from the fatty acid composition data. AI indicates the relationship between the sum of the main saturated fatty acids and that of the main classes of unsaturated. The main fatty acids of first class are designed as proatherogenic, which favors the adhesion of lipids to cells of the immunological and circulatory system; while the second-class fatty acids are considered as anti-atherogenic because they have an inhibiting effect on the aggregation of plaque and diminish the levels of esterified fatty acids, cholesterol, and phospholipids, thereby preventing the appearance of micro and macro-coronary diseases. These two indices were used in accordance with Ulbricht and Southgate (1991).

$$
\begin{aligned}
& \text { Atherogenicity Index }(\text { AI }) \\
& \text { AI }=[(C 12: 0+(4 \times C 14: 0)+\mathrm{C} 16: 0)] / \\
& {[\Sigma \text { MUFAs }+\Sigma \text { PUFA }(\mathrm{n}-6)+\Sigma \text { PUFA }(\mathrm{n}-3)]}
\end{aligned}
$$

Thrombogenicity index (TI). TI is defined by the relationship between the pro-thrombogenetic and the anti-thrombogenetic fatty acids. It reflects the state of the blood vessels while indicating the training clots (Senso et al. 200; Ulbritch and Southgate, 1991)

$$
\begin{gathered}
\text { TI }=[(\mathrm{C} 14: 0+\mathrm{C} 16: 0+\mathrm{C} 18: 0) /(0.50 * \Sigma \mathrm{MUFA})+ \\
(0.5 * \Sigma \text { PUFA }(\mathrm{n}-6)+(3 * \Sigma \mathrm{PUFA}(\mathrm{n}-3)+(\Sigma \mathrm{PUFA} \\
(\mathrm{n}-3) / \Sigma \text { PUFA }(\mathrm{n}-6)]
\end{gathered}
$$

\subsection{Statistical Analysis}

Statistical analysis of the effects of season and sex on total lipids and fatty acid composition was carried out with the SAS software program version 9.1. Different mean values were analyzed according to the Student Newman and Kull tests. Results are expressed as presentage $(\%)$ and $\mathrm{g} / 100 \mathrm{~g}$ of $\mathrm{ww}$, and are considered significant at $(p<0.05)$.

\section{RESULTS}

\subsection{Mackerel fillets proximate composition}

As reported in Table 2, moisture percentages for males in autumn, winter and summer were not significantly different $(p>0.05)$; while spring presented the lowest moisture value at $66 \%$. For females, moisture 
TABLE 2. Seasonal variation in proximate composition for males and females of Scomber scombrus.

\begin{tabular}{|c|c|c|c|c|}
\hline & Summer & Autumn & Winter & Spring \\
\hline \multicolumn{5}{|c|}{ Moisture (\%) } \\
\hline Male & $71.50 \pm 1.84^{\mathrm{a}, \mathrm{A}}$ & $71.02 \pm 0.60^{\mathrm{a}, \mathrm{A}}$ & $70.01 \pm 0.10^{\mathrm{a}, \mathrm{A}}$ & $66.03 \pm 1.60^{\mathrm{b}, \mathrm{A}}$ \\
\hline Female & $72.01 \pm 0.40^{\mathrm{a}, \mathrm{A}}$ & $70.05 \pm 0.50^{\mathrm{a}, \mathrm{A}}$ & $66.9 \pm 0.76^{\mathrm{b}, \mathrm{B}}$ & $67.90 \pm 1.12^{\mathrm{b}, \mathrm{A}}$ \\
\hline \multicolumn{5}{|l|}{ Lipid (\%) } \\
\hline Male & $5.37 \pm 1.30^{\mathrm{a}, \mathrm{A}}$ & $5.70 \pm 0.68^{\mathrm{a}, \mathrm{A}}$ & $6.05 \pm 1.30^{\mathrm{a}, \mathrm{A}}$ & $18.86 \pm 1.70^{\mathrm{b}, \mathrm{A}}$ \\
\hline Female & $3.39 \pm 0.20^{\mathrm{a}, \mathrm{B}}$ & $9.01 \pm 1.22^{\mathrm{a}, \mathrm{B}}$ & $11.92 \pm 0.80^{\mathrm{b}, \mathrm{B}}$ & $13.21 \pm 2.10^{\mathrm{b}, \mathrm{B}}$ \\
\hline \multicolumn{5}{|c|}{ Protein (\%) } \\
\hline Male & $21.80 \pm 1.16^{\mathrm{a}, \mathrm{A}}$ & $22.03 \pm 2.80^{\mathrm{a}, \mathrm{A}}$ & $21.54 \pm 2.09^{\mathrm{a}, \mathrm{A}}$ & $18.20 \pm 1.80^{\mathrm{a}, \mathrm{A}}$ \\
\hline Female & $22.07 \pm 1.70^{\mathrm{a}, \mathrm{A}}$ & $20.00 \pm 1.05^{\mathrm{a}, \mathrm{A}}$ & $20.05 \pm 0.63^{\mathrm{a}, \mathrm{A}}$ & $18.00 \pm 1.32^{\mathrm{a}, \mathrm{A}}$ \\
\hline \multicolumn{5}{|l|}{ Ash (\%) } \\
\hline Male & $1.33 \pm 0.23^{\mathrm{a}, \mathrm{A}}$ & $1.10 \pm 0.35^{\mathrm{a}, \mathrm{A}}$ & $1.30 \pm 0.29^{\mathrm{a}, \mathrm{A}}$ & $1.00 \pm 0.30^{\mathrm{a}, \mathrm{A}}$ \\
\hline Female & $2.00 \pm 0.29^{\mathrm{a}, \mathrm{B}}$ & $1.00 \pm 0.06^{\mathrm{a}, \mathrm{A}}$ & $1.05 \pm 0.22^{\mathrm{a}, \mathrm{A}}$ & $0.98 \pm 0.41^{\mathrm{a}, \mathrm{A}}$ \\
\hline
\end{tabular}

Results are given as mean $\pm \mathrm{SD}(\mathrm{n}=6: 3$ males +3 females by month),

Different letters for the same line (lower case) indicate significant differences among seasons, and different letters for the same column (capital) indicate significant differences between sexes $(P<0.05)$, according to the Student Newman and Kull tests.

Values with the same superscripts are not significantly different at $(P<0.05)$, according to the Student Newman and Kull tests.

TABLE 3. Seasonal variation in Scomber scombrus fatty acid composition for males ( $\%$ of total fatty acids)

\begin{tabular}{lcccc}
\hline Fatty acids & Summer & Autumn & Winter & Spring \\
\hline C14:0 & $1.42 \pm 0.90^{\mathrm{a}}$ & $2.04 \pm 0.32^{\mathrm{a}}$ & $1.11 \pm 0.43^{\mathrm{a}}$ & $2.14 \pm 0.45^{\mathrm{a}}$ \\
C16:0 & $22.18 \pm 1.63^{\mathrm{a}}$ & $24.13 \pm 2.75^{\mathrm{a}}$ & $22.43 \pm 2.11^{\mathrm{a}}$ & $23.97 \pm 1.38^{\mathrm{a}}$ \\
C18:0 & $11.42 \pm 1.04^{\mathrm{a}}$ & $10.39 \pm 0.95^{\mathrm{b}}$ & $10.68 \pm 0.67^{\mathrm{b}}$ & $9.26 \pm 0.91^{\mathrm{b}}$ \\
C16:1 & $2.22 \pm 0.27^{\mathrm{a}}$ & $3.93 \pm 0.04^{\mathrm{a}}$ & $2.72 \pm 0.15^{\mathrm{a}}$ & $3.45 \pm 0.07^{\mathrm{a}}$ \\
C18:1 & $9.77 \pm 1.09^{\mathrm{a}}$ & $12.01 \pm 2.51^{\mathrm{b}}$ & $9.51 \pm 1.03^{\mathrm{a}}$ & $7.83 \pm 1.14^{\mathrm{a}}$ \\
C18:2 $\boldsymbol{n}$-6 & $1.15 \pm 0.27^{\mathrm{a}}$ & $1.47 \pm 0.04^{\mathrm{b}}$ & $1.43 \pm 0.15^{\mathrm{b}}$ & $1.03 \pm 0.07^{\mathrm{a}}$ \\
C18:3 $\boldsymbol{n}$-6 & $0.25 \pm 0.07^{\mathrm{a}}$ & $0.19 \pm 0.08^{\mathrm{a}}$ & $0.20 \pm 0.05^{\mathrm{a}}$ & $0.14 \pm 0.05^{\mathrm{a}}$ \\
C20:2 $\boldsymbol{n}$-6 & $0.18 \pm 0.03^{\mathrm{a}}$ & $0.26 \pm 0.06^{\mathrm{b}}$ & $0.11 \pm 0.06^{\mathrm{a}}$ & $0.17 \pm 0.03^{\mathrm{a}}$ \\
C20:3 $\boldsymbol{n}$-6 & $0.44 \pm 0.08^{\mathrm{a}}$ & $0.32 \pm 0.03^{\mathrm{b}}$ & $0.20 \pm 0.04^{\mathrm{c}}$ & $0.29 \pm 0.07^{\mathrm{c}}$ \\
C20:4 $\boldsymbol{n}$-6 & $2.88 \pm 0.25^{\mathrm{a}}$ & $3.55 \pm 0.50^{\mathrm{b}}$ & $3.68 \pm 0.28^{\mathrm{b}}$ & $3.07 \pm 0.26^{\mathrm{b}}$ \\
C18:3 $\boldsymbol{n}$-3 & $0.36 \pm 0.08^{\mathrm{a}}$ & $0.42 \pm 0.16^{\mathrm{a}}$ & $0.48 \pm 0.07^{\mathrm{a}}$ & $0.67 \pm 0.03^{\mathrm{b}}$ \\
C20:5 $\boldsymbol{n}$-3 & $5.04 \pm 0.67^{\mathrm{a}}$ & $5.80 \pm 0.28^{\mathrm{a}}$ & $4.76 \pm 0.12^{\mathrm{a}}$ & $6.58 \pm 0.56^{\mathrm{a}}$ \\
C22:5 $\boldsymbol{n}$-3 & $1.51 \pm 0.05^{\mathrm{a}}$ & $1.30 \pm 0.20^{\mathrm{a}}$ & $1.16 \pm 0.30^{\mathrm{b}}$ & $1.70 \pm 0.03^{\mathrm{c}}$ \\
C22:6 $\boldsymbol{n}$-3 & $41.19 \pm 1.21^{\mathrm{a}}$ & $34.17 \pm 1.96^{\mathrm{b}}$ & $41.52 \pm 0.32^{\mathrm{a}}$ & $39.66 \pm 1.90^{\mathrm{ab}}$ \\
\hline
\end{tabular}

Results are given as mean $\pm \mathrm{SD}(\mathrm{n}=3$ males in each month)

Different letters indicate significant differences among seasons $(P<0.05)$, according to the Student Newman and Kull tests.

Values with the same superscripts (a and c) are not significantly different $(P<0.05)$, according to the Student Newman and Kull tests.

seasonal variation was significant $(p<0.05)$, and the lowest values were obtained in winter and spring, with 67 and 68\%, respectively. Mackerel fillet composition showed a high lipid level in spring for both males and females with 18.9 and $13.2 \%$, decreasing significantly $(p<0.05)$ in summer to 5.4 and $3.4 \%$, respectively. Season and sex variations in lipid contents were highly significant $(p<0.05)$. Protein contents ranged from 18 to $22 \%$; the highest levels for females and males were obtained in summer with 22 and $21.8 \%$, respectively. No significant differences in protein content between seasons and sex were observed $(p>$ 0.05 ). Ash content ranged from 1 to $2 \%$ and seasonal variations were significant $(\mathrm{p}<0.05)$. There was no significant difference between sexes $(p>0.05)$. High levels were obtained in summer for females and males with 2 and $1.3 \%$, respectively.

\subsection{Fatty acids composition}

Gas chromatography (GC) analysis allowed the identification of diffrent categories of fatty acids as reported in Tables 3 and 4 . The saturated fatty acids (SFA), monounsaturated fatty acids (MUFA), and polyunsaturated fatty acids (PUFA); PUFA/SFA and $\mathrm{n}-3 / \mathrm{n}-6$ ratios for both sexes are summarized in Table 5 . 
Sex and seasonal variation in proximate composition and fatty acid profile of Scomber scombrus 5

TABLE 4. Seasonal variation in Scomber scombrus fatty acid composition for females ( $\%$ of total fatty acids)

\begin{tabular}{|c|c|c|c|c|}
\hline Fatty acids & Summer & Autumn & Winter & Spring \\
\hline C14:0 & $1.42 \pm 0.90^{\mathrm{a}}$ & $2.04 \pm 0.32^{\mathrm{a}}$ & $1.11 \pm 0.43^{\mathrm{a}}$ & $2.14 \pm 0.45^{\mathrm{a}}$ \\
\hline C16:0 & $22.18 \pm 1.63^{\mathrm{a}}$ & $24.13 \pm 2.75^{\mathrm{a}}$ & $22.43 \pm 2.11^{\mathrm{a}}$ & $23.97 \pm 1.38^{\mathrm{a}}$ \\
\hline C18:0 & $11.42 \pm 1.04^{\mathrm{a}}$ & $10.39 \pm 0.95^{\mathrm{b}}$ & $10.68 \pm 0.67^{\mathrm{b}}$ & $9.26 \pm 0.91^{\mathrm{b}}$ \\
\hline C16:1 & $2.22 \pm 0.27^{\mathrm{a}}$ & $3.93 \pm 0.04^{\mathrm{a}}$ & $2.72 \pm 0.15^{\mathrm{a}}$ & $3.45 \pm 0.07^{\mathrm{a}}$ \\
\hline C18:1 & $9.77 \pm 1.09^{\mathrm{a}}$ & $12.01 \pm 2.51^{\mathrm{b}}$ & $9.51 \pm 1.03^{\mathrm{a}}$ & $7.83 \pm 1.14^{\mathrm{a}}$ \\
\hline C18:2 $n-6$ & $1.15 \pm 0.27^{\mathrm{a}}$ & $1.47 \pm 0.04^{\mathrm{b}}$ & $1.43 \pm 0.15^{\mathrm{b}}$ & $1.03 \pm 0.07^{\mathrm{a}}$ \\
\hline C18:3 n-6 & $0.25 \pm 0.07^{\mathrm{a}}$ & $0.19 \pm 0.08^{\mathrm{a}}$ & $0.20 \pm 0.05^{\mathrm{a}}$ & $0.14 \pm 0.05^{\mathrm{a}}$ \\
\hline C20:2 n-6 & $0.18 \pm 0.03^{\mathrm{a}}$ & $0.26 \pm 0.06^{\mathrm{b}}$ & $0.11 \pm 0.06^{\mathrm{a}}$ & $0.17 \pm 0.03^{\mathrm{a}}$ \\
\hline C20:3 n-6 & $0.44 \pm 0.08^{\mathrm{a}}$ & $0.32 \pm 0.03^{\mathrm{b}}$ & $0.20 \pm 0.04^{\mathrm{c}}$ & $0.29 \pm 0.07^{\mathrm{c}}$ \\
\hline C20:4 n-6 & $2.88 \pm 0.25^{\mathrm{a}}$ & $3.55 \pm 0.50^{\mathrm{b}}$ & $3.68 \pm 0.28^{\mathrm{b}}$ & $3.07 \pm 0.26^{\mathrm{b}}$ \\
\hline C18:3 n-3 & $0.36 \pm 0.08^{\mathrm{a}}$ & $0.42 \pm 0.16^{\mathrm{a}}$ & $0.48 \pm 0.07^{\mathrm{a}}$ & $0.67 \pm 0.03^{b}$ \\
\hline C20:5 n-3 & $5.04 \pm 0.67^{\mathrm{a}}$ & $5.80 \pm 0.28^{\mathrm{a}}$ & $4.76 \pm 0.12^{\mathrm{a}}$ & $6.58 \pm 0.56^{\mathrm{a}}$ \\
\hline C22:5 n-3 & $1.51 \pm 0.05^{\mathrm{a}}$ & $1.30 \pm 0.20^{\mathrm{a}}$ & $1.16 \pm 0.30^{\mathrm{b}}$ & $1.70 \pm 0.03^{\mathrm{c}}$ \\
\hline $\mathrm{C} 22: 6 n-3$ & $41.19 \pm 1.21^{\mathrm{a}}$ & $34.17 \pm 1.96^{\mathrm{b}}$ & $41.52 \pm 0.32^{\mathrm{a}}$ & $39.66 \pm 1.90^{\mathrm{ab}}$ \\
\hline
\end{tabular}

Results are given as mean $\pm \mathrm{SD}$ ( $\mathrm{n}=3$ females in each month)

Different letters indicate significant differences among seasons $(P<0.05)$, according to the Student Newman and Kull tests.

Values with the same superscripts ( $\mathrm{a}$ and $\mathrm{c}$ ) are not significantly different at $(P<0.05)$, according to the Student Newman and Kull tests.

The SFA are represented by myristic (C14:0), palmitic (C16:0), and stearic (C18:0) acids. Palmitic acid (C16:0) was the major fatty acid in the SFA. The highest values were obtained in autumn with 25 and $24.1 \%$ for males and females, respectively. The lowest values were obtained in summer with 20 and $22.2 \%$ for males and females, respectively. There were no significant differences among seasons and sexes $(p>0.05)$. The highest values for myristic acid (C14:0) were registered in autumn for males with $3.6 \%$ and in spring for females with $2.1 \%$. The lowest levels were observed in summer and in winter with 0.9 and $1.1 \%$ for males and females, respectively. Myristic acid was significantly different among seasons $(p<0.05)$ but not between females and males $(p>0.05)$. The highest percentages for stearic acid (C18:0) were obtained in autumn for males $(11.2 \%)$ and in summer for females (11.4\%). Nevertheless, the lowest values were obtained in spring with 8.6 and $9.3 \%$ for males and females, respectively. Stearic fatty acid was significantly different among seasons $(p<0.05)$, but not between females and males $(p>$ 0.05 ). SFAs mean values for males and females were 34.9 and $35.3 \%$, respectively; there was no significant difference among seasons and sexes for SFAs $(\mathrm{p}>0.05)$.

The MUFA are represented by palmitoleic $(\mathrm{C} 16: 1 n-7)$ and oleic $(\mathrm{C} 18: 1 n-9)$ acids. Oleic acid (C18:1) was the major fatty acid in MUFA. The highest values were obtained in autumn for males and females with 15.8 and $12 \%$, respectively. The lowest levels were obtained in summer with 5.8\% for males and in spring for females with $7.8 \%$. There were no significant differences among seasons and sexes $(p<0.05)$. The highest values were obtained for palmitoleic acid in autumn for males at 5.2\% and for females at $4 \%$. The lowest levels were registered in summer for males at $1.7 \%$ and females at $2.2 \%$. There were no significant differences among seasons and sexes $(p>0.05)$. The mean MUFA values for males and females were 12.9 and $13.5 \%$, respectively; whereas MUFA average values during the study period ranged from $11.6 \%$ in autumn to $14 \%$ in winter. There were no significant differences among seasons and sexes $(p<0.05)$.

The PUFAs are divided into two families, those of the $n-3$ and $n-6$ series. The n-3 fatty acids are mainly represented by linolenic (C18:3n-3), docosapentaenoic (DPA, C20:5, $n$-3) and docosahexaenoic (DHA, C22:6 n-3). The n-6 fatty acids are mainly represented by linoleic $(\mathrm{C} 18: 2 \mathrm{n}-6)$ and arachidonic $(\mathrm{C} 20: 4 n-6)$. The PUFAs were the most prominant in Scomber scombrus lipid contents. Seasonal variations in these FAs were significant $(p<0.05)$, although the sex variation was not $(\mathrm{p}>0.05)$. The highest PUFA levels were related to those of the n-3 family, mainly represented by the EPA and the DHA. The highest levels for EPA were registered in spring with 8.3 and $6.6 \%$ for males and females, respectively. The lowest values were obtained in winter with 5.1 and $4.8 \%$ for males and females, respectively. DHA was the most abundant fatty acid in the $n-3$ family; its highest values were noted in summer with $48.6 \%$ for males and in winter for females with $41.5 \%$. We also noted that females were rich in DHA in summer with $41.2 \%$. The lowest levels were obtained in autumn with 23.2 and $34.2 \%$ for males and females, respectively. 
TABLE 5. Seasonal variations in EPA, DHA, SFA, MUFA, PUFA (n-3), PUFA (n-6) and ratio for Scomber scombrus males and females.

\begin{tabular}{|c|c|c|c|c|}
\hline & Summer & Autumn & Winter & Spring \\
\hline \multicolumn{5}{|c|}{ C20:5 n-3 (EPA \%) } \\
\hline Male & $5.33 \pm 0.33^{\mathrm{a}, \mathrm{A}}$ & $7.07 \pm 0.43^{\mathrm{b}, \mathrm{A}}$ & $5.12 \pm 0.03^{\mathrm{a}, \mathrm{A}}$ & $8.29 \pm 1.54^{\mathrm{b}, \mathrm{A}}$ \\
\hline Female & $5.04 \pm 0.67^{\mathrm{a}, \mathrm{A}}$ & $5.80 \pm 0.28^{\mathrm{a}, \mathrm{B}}$ & $4.76 \pm 0.12^{\mathrm{a}, \mathrm{A}}$ & $6.58 \pm 0.56^{\mathrm{a}, \mathrm{A}}$ \\
\hline \multicolumn{5}{|c|}{ C22:6 n-3 (DHA \%) } \\
\hline Male & $48.58 \pm 1.97^{\mathrm{a}, \mathrm{A}}$ & $23.25 \pm 1.56^{\mathrm{b}, \mathrm{A}}$ & $40.14 \pm 2.55^{\mathrm{c}, \mathrm{A}}$ & $38.78 \pm 2.17^{\mathrm{c}, \mathrm{A}}$ \\
\hline Female & $41.19 \pm 1.21^{\mathrm{a}, \mathrm{A}}$ & $34.17 \pm 1.96^{\mathrm{b}, \mathrm{B}}$ & $41.52 \pm 0.32^{\mathrm{a}, \mathrm{A}}$ & $39.66 \pm 1.90^{\mathrm{ab}, \mathrm{A}}$ \\
\hline \multicolumn{5}{|l|}{$\Sigma$ SFA $(\%)$} \\
\hline Male & $31.60^{\mathrm{a}, \mathrm{A}}$ & $39.92^{\mathrm{a}, \mathrm{A}}$ & $34.70^{\mathrm{a}, \mathrm{A}}$ & $33.20^{\mathrm{a}, \mathrm{A}}$ \\
\hline Female & $35.02^{\mathrm{a}, \mathrm{A}}$ & $36.56^{\mathrm{a}, \mathrm{A}}$ & $34.12^{\mathrm{a}, \mathrm{A}}$ & $35.37^{\mathrm{a}, \mathrm{A}}$ \\
\hline \multicolumn{5}{|c|}{$\Sigma$ MUFA (\%) } \\
\hline Male & $7.40^{\mathrm{a}, \mathrm{A}}$ & $20.99^{\mathrm{b}, \mathrm{A}}$ & $12.98^{\mathrm{c}, \mathrm{A}}$ & $12.98^{\mathrm{c}, \mathrm{A}}$ \\
\hline Female & $11.99^{\mathrm{a}, \mathrm{B}}$ & $15.94^{\mathrm{b}, \mathrm{B}}$ & $12.23^{\mathrm{a}, \mathrm{A}}$ & $11.28^{\mathrm{a}, \mathrm{A}}$ \\
\hline \multicolumn{5}{|c|}{$\Sigma$ PUFA $n-6(\%)$} \\
\hline Male & $5.16^{\mathrm{a}, \mathrm{A}}$ & $6.13^{\mathrm{a}, \mathrm{A}}$ & $5.06^{\mathrm{a}, \mathrm{A}}$ & $4.41^{\mathrm{a}, \mathrm{A}}$ \\
\hline Female & $4.46^{\mathrm{a}, \mathrm{A}}$ & $5.47^{\mathrm{a}, \mathrm{A}}$ & $5.42^{\mathrm{a}, \mathrm{A}}$ & $4.41^{\mathrm{a}, \mathrm{A}}$ \\
\hline \multicolumn{5}{|c|}{$\Sigma$ PUFA $n-3(\%)$} \\
\hline Male & $55.83^{\mathrm{a}, \mathrm{A}}$ & $32.94^{\mathrm{b}, \mathrm{A}}$ & $47.27^{\mathrm{a}, \mathrm{A}}$ & $49.41^{\mathrm{a}, \mathrm{A}}$ \\
\hline Female & $48.54^{\mathrm{a}, \mathrm{B}}$ & $42.01^{\mathrm{a}, \mathrm{B}}$ & $48.12^{\mathrm{a}, \mathrm{A}}$ & $48.93^{\mathrm{a}, \mathrm{A}}$ \\
\hline \multicolumn{5}{|c|}{ PUFA/SFA } \\
\hline Male & $1.93^{\mathrm{a}, \mathrm{A}}$ & $0.97^{\mathrm{a}, \mathrm{A}}$ & $1.50^{\mathrm{a}, \mathrm{A}}$ & $1.62^{\mathrm{a}, \mathrm{A}}$ \\
\hline Female & $1.51^{\mathrm{a}, \mathrm{A}}$ & $1.29^{\mathrm{a}, \mathrm{A}}$ & $1.56^{\mathrm{a}, \mathrm{A}}$ & $1.50^{\mathrm{a}, \mathrm{A}}$ \\
\hline \multicolumn{5}{|l|}{$n-3 / n-6$} \\
\hline Male & $10.81^{\mathrm{a}, \mathrm{A}}$ & $5.37^{\mathrm{b}, \mathrm{A}}$ & $9.34^{\mathrm{a}, \mathrm{A}}$ & $11.20^{\mathrm{a}, \mathrm{A}}$ \\
\hline Female & $10.88^{\mathrm{a}, \mathrm{A}}$ & $7.68^{\mathrm{a}, \mathrm{A}}$ & $8.87^{\mathrm{a}, \mathrm{A}}$ & $11.09^{\mathrm{a}, \mathrm{A}}$ \\
\hline \multicolumn{5}{|c|}{ EPA $(\mathrm{mg} / 100 \mathrm{~g}$ of $\mathrm{w} / \mathrm{w})$} \\
\hline Male & $23.37 \pm 1.48^{\mathrm{a}, \mathrm{A}}$ & $16.94 \pm 3.82^{\mathrm{b}, \mathrm{A}}$ & $14.42 \pm 0.45^{\mathrm{b}, \mathrm{A}}$ & $25.49 \pm 1.72^{\mathrm{b}, \mathrm{A}}$ \\
\hline Female & $31.96 \pm 1.49^{\mathrm{a}, \mathrm{B}}$ & $26.74 \pm 5.27^{\mathrm{a}, \mathrm{B}}$ & $59.36 \pm 6.56^{\mathrm{a}, \mathrm{B}}$ & $15.74 \pm 3.04^{\mathrm{a}, \mathrm{B}}$ \\
\hline \multicolumn{5}{|c|}{ DHA (mg/100g of w/w) } \\
\hline Male & $163.73 \pm 18.47^{\mathrm{a}, \mathrm{A}}$ & $60.70 \pm 7.79^{\mathrm{b}, \mathrm{A}}$ & $113.1 \pm 1.03^{\mathrm{c}, \mathrm{A}}$ & $125.70 \pm 7.12^{\mathrm{cA}}$ \\
\hline Female & $279.27 \pm 7.32^{\mathrm{a}, \mathrm{B}}$ & $113.30 \pm 15.20^{\mathrm{a}, \mathrm{B}}$ & $185.37 \pm 16.6^{\mathrm{a}, \mathrm{B}}$ & $100.89 \pm 7.90^{\mathrm{a}, \mathrm{A}}$ \\
\hline \multicolumn{5}{|c|}{$\Sigma$ PUFA $n-6(\mathrm{mg} / 100 \mathrm{~g}$ of $\mathrm{w} / \mathrm{w})$} \\
\hline Male & $22.84^{\mathrm{a}, \mathrm{A}}$ & $20.00^{\mathrm{a}, \mathrm{A}}$ & $16.78^{\mathrm{bA}}$ & $14.97^{\mathrm{b}, \mathrm{A}}$ \\
\hline Female & $25.96^{\mathrm{a}, \mathrm{A}}$ & $18.55^{\mathrm{a}, \mathrm{A}}$ & $31.78^{\mathrm{a}, \mathrm{B}}$ & $11.58^{\mathrm{a}, \mathrm{B}}$ \\
\hline \multicolumn{5}{|c|}{$\Sigma$ PUFA $n-3(\mathrm{mg} / 100 \mathrm{~g}$ of $\mathrm{w} / \mathrm{w})$} \\
\hline Male & $191.20^{\mathrm{a}, \mathrm{A}}$ & $82.66^{\mathrm{b}, \mathrm{A}}$ & $133.28^{\mathrm{c}, \mathrm{A}}$ & $152.18^{\mathrm{d}, \mathrm{A}}$ \\
\hline Female & $333.70^{\mathrm{a}, \mathrm{B}}$ & $146.00^{\mathrm{b}, \mathrm{B}}$ & $230.00^{\mathrm{c}, \mathrm{B}}$ & $122.00^{\mathrm{d}, \mathrm{B}}$ \\
\hline
\end{tabular}

Results are given as mean \pm SD ( $n=6: 3$ males and 3 females in each month),

Different letters for the same line (lower case) indicate significant differences among seasons, and different letters for the same column (capital) indicate significant differences between sexes $(P<0.05)$, according to the Student Newman and Kull tests.

Values with the same superscripts are not significantly different at $(P<0.05)$, according to the Student Newman and Kull tests. SFA: saturated fatty acids. MUFA: monounsaturated fatty acids. PUFA: polyunsaturated fatty acids

PUFA n-3 mean values for males and females were 47 and $45.8 \%$, respectively; whereas seasonal variation was significant $(p<0.05)$. Average values during the study period ranged from $42 \%$ in winter to $49 \%$ in autumn. PUFA n-3 series was significantly different among seasons $(p<0.05)$ but not between sexes $(p>0.05)$.
The highest proportion of n-6 PUFAs was arachidonic acid (C20:4 n-6), whose values varied significantly with season $(p<0.05)$; the maximum level was obtained in autumn for males with $3.8 \%$ and in winter for females with 3.7\%. PUFA n-6 mean values for males and females were 5.5 and 5.3\%, respectively. Average values during the study period 
ranged from 4.7 in summer to $6 \%$ in winter. PUFA $\mathrm{n}-6$ was significantly different among seasons $(p<$ 0.05 ) but not between sexes $(p>0.05)$.

The PUFA/SFA ratio ranged from 1 to 2 . The maximum values were obtained in summer for males with 2 and in winter for females with 1.6. Season and sex variations in the PUFA/SFA ratio were insignificant $(p>0.05)$. Mean values for males and females were 1.6 and 1.5 , respectively; whereas average values during the study period ranged from 1.3 in winter to 1.6 in autumn. The highest levels for the $n-3 / n-6$ were registered in spring with 11.2 and 11 for males and females, respectively. There were no significant differences in the $n-3 / n-6$ ratio among seasons and sexes $(p>0.05)$. Mean values for males and females were 8.8; whereas average values during the study period ranged from 7.2 in winter to 10.4 in summer (Table 5).

For both sexes, EPA, DHA, PUFA $n-3$ and PUFA $n-6$ results are expressed by $\mathrm{mg} / 100 \mathrm{~g}$ of ww and are indicated in Table 5. For EPA and DHA, a significant difference among sexes and seasons was observed only for males $(\mathrm{p}<0.05)$. The highest EPA quantity was obtained in spring for males, with 25.5 $\mathrm{mg} / 100 \mathrm{~g}$ of ww and in winter for females with 59.4 $\mathrm{mg} / 100 \mathrm{gww}$. The highest DHA values were recorded in summer for males and females with $163.8 \mathrm{mg} / 100 \mathrm{~g}$ of $\mathrm{ww}$ and $279.3 \mathrm{mg} / 100 \mathrm{~g}$ of $\mathrm{ww}$, respectively.

For both sexes, the highest PUFA $n-3$ values were observed in summer with $191.2 \mathrm{mg} / 100 \mathrm{~g}$ of ww for males and $333.7 \mathrm{mg} / 100 \mathrm{~g}$ of $\mathrm{ww}$ for females. There were significant diferences among seasons and sexes $(\mathrm{p}<0.05)$.

\subsection{Nutritional quality index}

The Atherogenicity index (AI) and the Thrombogenicity index (TI) were calculated for the both sexes and all seasons (Table 6). The AI index was comprised between 0.3 and 0.6 for males and between 0.4 and 0.5 for females. Duncan's test was significant $(p<0.05)$ for both sexes. The values for the TI index ranged from 0.6 to 0.8 for males, and was about 0.6 for females. For both sexes, Duncan's test was significant $(p<0.05)$ acording to season but it was not significant $(\mathrm{p}>0.05)$ between sexes.

\section{DISCUSSION}

\subsection{Scomber scombrus fillets' proximate composition}

The highest moisture percentages for males and females were associated with low levels of lipid contents, indicating that there is an inverse relationship among these compounds. Protein content for each sex showed a positive relation to moisture. The results for moisture are similiar to those of El Oudiani et al., (2016) in their study on Atlantic mackerel from the South East of Tunisia. Moreover, they are also in accordance with those indicated by Orban et al., (2011) on their study on Boops boops and Trachurus trachurus; and by Ben Rebah et al., (2014), who reported on the golden-grey mullet Liza aurata from the Tunisian coast; and by Anthony et al., (2000) who studied forage fish from the northern Gulf of Alaska, and demonstrated that a high-lipid fish has less water and more protein than low-lipid fish.

Mackerel flesh lipids were abundant and ranged from 3.4 to $19 \%$. They varied significantly $(\mathrm{p}<0.05)$ according to sex and season. Similar trends were obteined by Guizani and Moujahed (2015) and El Oudiani et al. (2016) in their studies on Atlantic mackerel from the North East and the South East of Tunisia, with values ranging from 4.35 to $11.53 \%$. Other authors such as Chanet et al., (2011) reported that lipids are abundant in fresh mackeral at more than $15 \%$, ranging from 5 to $30 \%$ depending on the season.

Seasonal variation in protein content was not significant $(\mathrm{p}>0.05)$ and was in agreement with Tzikas et al., (2007), who studied the Mediterranean horse mackerel Trachurus mediterraneus muscle from the North Aegean Sea. Moreover, according to Chanet et al., (2011) protein levels were about $19 \%$, and this value is included in the range obtained in the present data (18 to $22 \%)$.

The observed variations may be explained by the impact of both exogenous and endogenous factors, including environmental parameters and the physiological state of the fish. However, during reproductive periods, lipids and proteins are mobilized from

TABLE 6. Nutritional quality indexes of Scomber scombrus males and females

\begin{tabular}{llcccc}
\hline Indexes & Sexes & Summer & Autumn & Winter & Spring \\
\hline AI & Male & $0.45 \pm 0.03^{\mathrm{a}, \mathrm{A}}$ & $0.35 \pm 0.03^{\mathrm{a}, \mathrm{A}}$ & $0.67 \pm 0.15^{\mathrm{b}, \mathrm{A}}$ & $0.44 \pm 0.09^{\mathrm{a}, \mathrm{A}}$ \\
& Female & $0.50 \pm 0.04^{\mathrm{a}, \mathrm{A}}$ & $0.43 \pm 0.09^{\mathrm{a}, \mathrm{A}}$ & $0.51 \pm 0.04^{\mathrm{a}, \mathrm{A}}$ & $0.41 \pm 0.07^{\mathrm{a}, \mathrm{A}}$ \\
TI & Male & $0.60 \pm 0.05^{\mathrm{a}, \mathrm{A}}$ & $0.54 \pm 0.02^{\mathrm{a}, \mathrm{A}}$ & $0.80 \pm 0.30^{\mathrm{a}, \mathrm{A}}$ & $0.64 \pm 0.09^{\mathrm{a}, \mathrm{A}}$ \\
& Female & $0.65 \pm 0.05^{\mathrm{a}, \mathrm{A}}$ & $0.65 \pm 0.11^{\mathrm{a}, \mathrm{A}}$ & $0.69 \pm 0.10^{\mathrm{a}, \mathrm{A}}$ & $0.62 \pm 0.08^{\mathrm{a}, \mathrm{A}}$ \\
\hline
\end{tabular}

Results are given as mean $\pm \mathrm{SD}$ ( $\mathrm{n}=6: 3$ males +3 females in each month),

Different letters for the same line (lower case) indicate significant differences among seasons, and different letters for the same column (capital) indicate significant differences between sexes $(P<0.05)$, according to Duncan's tests.

Values with the same superscripts are not significantly different at $(P<0.05)$, according to Duncan's tests.

AI: Atherogenicity index; TI: Thrombogenicity index. 
muscle and transferred to the gonads, thus influencing its lipid content (Børresen, 1992; Pirini et al., 2010). Moreover, according to Wallace (1991), a study on mackerel from the western English Channel demonstrated that lipid content is correlated with the spawning period and its gonad maturation state. However, its fat fillet contents varied with season, at 25 to $30 \%$ in December when fish is well-fed, and around 5\% in May when the fish spawns.

Results of ash contents were in agreement with other fish species, as reported by Caponio et al., (2004). High ash levels are probably related to the size of fish and its feeding habit composition. Seasonal variation in ash contents was significant $(\mathrm{p}<0.05)$ as observed by Kacem et al., (2011) in other fish species such as Sardinella aurita, Sarpa salpa, and Sepia officinalis from the Tunisian coast.

\subsection{Scomber scombrus fatty acids profiles}

Gas chromatography analysis indicated the presence of three categories of fatty acids, essentially saturated SFAs, monounsaturated MUFAs and polyunsaturated PUFAs, whose compositions varied with season. This result is in line with Guizani and Moujahed (2015) and El Oudiani et al. (2016), who studdied Atlantic mackerel, and with other studies dealing with the viscera and edible parts of fish (Ben Rebah et al., 2009).

In the SFA family, palmitic acid (C16:0) was the most abundant fatty acid. This finding is in agreement with other studies carried out on different Mediterranean fish as reported by Ben Rebah et al., (2009). In fact, according to Andrade et al., (1995), palmitic acid is the key part of fish lipid metabolism. There were significant differences among seasons and sexes $(\mathrm{p}>0.05)$, which is in accordance with the results found by Bulla et al., (2011) on raw sardines (Sardinella Brasiliensis).

For all samples, myristic acid (C14:0) exhibited the lowest proportion. This result is in accordance with those of Rioux et al., (2001), who claimed that the lowest proportion in the animal body is represented by myristic acid, ranging between 0.5 and $2 \%$ of total fatty acids (TFAs).

In this data, the highest MUFA levels were registered in autumn for both males and females. This trend contradicts Soriguer et al., (1997), who studied Atlantic mackerel from Spain and found that the highest MUFA levels were found in winter. This difference may be explained by the effect of environmental parameters, essentially temperature, and probably the physiological state of the fish. In fact, Dalsgaard et al. (2003) signaled that high MUFA levels are an indicator of a high degree of carnivory of the species. However, according to Lee et al., (2006), MUFA levels are correlated with the mackerel's diet composition and its high degree of carnivory. Pepin et al., (1988) reported that Atlantic mackerel is an opportunistic fish species, whose diet composition is based on zooplankton, crustaceans such as copepods (copepod nauplii and adult copepod at its larval stage and at juvenile stage, amphipods, mysid shrimp) and mollusks. In our study the highest proportions of MUFAs were oleic acid. This result is in accordance with Ben Rebah, et al., (2014) on males of liza aurata from the Tunisian coast. In fact, oleic acid is characteristic of fish tissue and is actively synthesized by cells; under the action of ACAT (acyl CoA-cholesterol acyl transferase), oleic acid binds to cholesterol. The formed cholesterol esters are evidence of the form of transport of cholesterol in lipoproteins (Shirai et al., 2002; Legrand, 2007).

In comparison with SFAs and MUFAs, PUFAs constitute the largest part of mackerel lipid muscles. This result is in accordance with Özogul et al. (2007), who studied Scomber scombrus from the Marmara Sea and with Guizani and Moujahed (2015) and El Oudiani et al. (2016), who studied the Atlantic mackerel from the North and South East of Tunisia. The highest PUFA levels are those of the $n-3$ PUFA family, mainly represented by (EPA, C20:5n-3) and (DHA, C22:6 n-3). Concerning the $n-6$ PUFA family, the highest proportion was that of arachidonic acid (C20:4 n-6); which varied significantly among seasons $(p<0.05)$, but not between sexes $(p>0.05)$.

The seasonal variability in PUFA peaks may be explained by the impact of temperature, food availability, competition for food during each catching season and the physiological state of the fish. The effect of temperature on PUFA was studied by Paulina et al., (2016), who claimed that the unsaturation of the fatty acids in mackerel depends on geographical location. In fact, the ocean temperature was probably responsible for these changes. Therefore, the highest temperatures in the East of Iceland can explain the high saturation degree; while the lowest temperatures in the Northeast of Iceland are responsible of the lowest saturation and elevation in unsaturated degree of fatty acids. Moreover, according to Dwyer et al., (2003), in a trophic relationship the predator's fatty acid composition depends on its feeding preferences. This linkage provides an opportunity for the identification of trophic relationships in the marine environment and the correlation between fatty acids and diet composition, leading to the identification of the climatic process and to better knowledge on ecosystem dynamics (Dalsgaard et al., 2003).

In our study, the decrease in PUFA levels for both males and females was observed in autumn with 39 and $47.5 \%$, respectively. This decrease may be explained by the mobilization of fish fat reserves serving for gonad maturation. According to Garrido et al., (2008), food availability during the reproduction resting stage influences the amount of fat content accumulated by sardines before the spawning season and hence impacts the reproduction process. 
In our study PUFA/SFA ratio values varied from 1 to 2 for males and from 1.3 to 1.6 for females. The highest levels were obtained in summer for males and in winter for females; whereas lowest levels were obtained in autumn for both sexes. The mínimum ratio value recommended is 0.45 (HMSO, 1994).

The established n-3/n-6 ratios showed high levels in spring for both males and females with 11.2 and 11, respectively. In fact, according to Özogul et al., (2007) the n-3/n-6 ratio for marine fish species varies from 5 to 10 or more, which is in accordance with our findings, which ranged from 5.4 to 11.2.

In the present data EPA + DHA concentration for males ranged from $77 \mathrm{mg} / 100 \mathrm{gww}$ in autumn to $186 \mathrm{mg} / 100 \mathrm{~g}$ ww in summer. For females EPA + DHA concentration ranged from $117 \mathrm{mg} / 100 \mathrm{~g}$ ww in spring to $311 \mathrm{mg} / 100 \mathrm{~g} \mathrm{ww}$ in summer. We deduced that in summer we have the highest EPA+DHA concentrations for males and females. The obtained values are in accordance with the recommendations of the organizations listed below and are included in the range recommended by the International Society for the Study of Fatty Acids and Lipids (ISSFAL), which is $300-400 \mathrm{mg}$ EPA+DHA / day for the general adult population, which corresponds to 2-3 servings/wk of fish. Moreover, the AFFSA organization France (2013) recommends $500 \mathrm{mg} \mathrm{EPA}+\mathrm{DHA} /$ day with $(250 \mathrm{mg} \mathrm{EPA}+250$ mg DHA) for the general adult population. The NATO workshop on $\omega-3$ and $\omega-6$ fatty acids recommends 300-400 mg EPA+DHA/day for the general adult population, Simopolous (1989). The German society for nutrition and healthy start - young family network recommend $250 \mathrm{mg}$ LCPUFA /day for primary prevention of CVD. In order to supply the recommended $200 \mathrm{mg} /$ day of DHA, one should consume 2 servings/wk of marine fish, including at least one serving of fatty sea fish (such as mackerel, herring, sardine, salmon) for pregnant women.

\subsection{Nutritional quality indexes}

In our study the AI mean value for males and females was about 0.5 . This value is lower than those found by Turan et al., (2011) in their study on Crangon crangon and Raja clavata from the Black sea which were about 1.35 and 2.37 , respectively; and that of Valfre, et al., (2003) in their study on anchovy, which was about 1.35 . TI mean value for males and females was about 0.65 . This value is close to that found by Valfre et al., (2003) in their study on anchovy (0.45).

\section{CONCLUSIONS}

From the nutritional point of view, and whether it be male or female, Scomber scombrus fillets are characterized by high levels of fats and protein contents and by a high proportion of $n-3$ PUFAs, mainly DHA. Based on EPA + DHA concentrations, summer seems to be the most favorable period for its consumption, when these nutrients are at their optimal levels. The levels of these valuable components vary seasonally and depend on fish diet composition and environemental parameters. These variations are reflected in fish body composition, influencing the physiological state of the fish, spawning, reproduction, growth, recruitment and survival at younger stages.

\section{REFERENCES}

AFFSA. 2013. Avis de l'Agence française de sécurité sanitaire des aliments relatif à l'actualisation des apports nutritionnels conseillés pour les acides gras. France.

Andrade AD, Rubira AF, Matsushita M, Souza NE.1995. Omega-3 fatty acids in freshwater fish from South Brazil. J. Am. Oil. Chem. Soc. 72, 1207-1210.

Anthony JA, Roby DD, Turco KR. 2000. Lipid content and energy density of forage fishes from the northern Gulf of Alaska. J. Exp. Mar. Biol. Ecol. 248, 53-78. https://doi. org/10.1016/S0022-0981(00)00159-3

AOAC. (1990). Official Methods of Analysis, $15^{\text {th }}$ Edn. AOAC, Washington, D.C, pp 556.

Ben Rebah FB, Khitouni IK, Mihoubi NB, Bouain A. 2014. Seasonal variations in proximate and fatty acid composition of golden grey mullet Liza aurata $(\mathrm{R}, 1810)$ from the Tunisian coast. Int. J. Agric. Pol. Res. 2, 273-280.

Ben Rebah FB, Abdelmouleh A, Kammoun W, Yezza A. 2009. Seasonal variation of lipid content and fatty acid composition of Sardinella aurita from the Tunisian coast. J. Mar. Biol. Assoc. 90, 569-573. https://doi.org/10.1017/ S0025315409990658

Børresen T. 1992. Quality aspects of wild and reared fish. In: Huss HH, Jacobsen M, Liston J (eds.) Quality Assurance in the Fish Industry. Proceedings of an International Conference, Copenhagen, Denmark, August 1991. Elsevier, Amsterdam, 1-17.

Bulla MK, Simionato JI, Matsushita M, Garcia-Coró FA, Shimokomaki M, Visentainer JV, de Souza NE. 2011. Proximate Composition and Fatty Acid Profile of Raw and Roasted Salt Dried Sardines (Sardinella Brasiliensis). Food Nutr. Sci. 2, 440-443. https://doi.org/10.4236/fns.2011. 25062

Caponio F, Lestingi A, Summo C, Bilancia MT, Laudadio V. 2004. Chemical characteristics and lipid fraction quality of sardines (Sardina pilchardus): influence of sex and length. J. Appl. Ichthyol. 20, 530-535. https://doi. org/10.1111/j.1439-0426.2004.00611.x

Chanet B, Fusellier M, Guintard C. 2011. Influence of Flesh Composition on Radiographs and MRI Conducted on Alcohol Preserved Specimens of Taxonomic Collections. Cahiers d'Anatomie Comparée. 3, 1-7.

Dalsgaard J, St John M, Kattner G, Muller-Navarra D, Hagen W. 2003. Fatty acid trophic markers in the pelagic marine environment. Adv. Mar. Biol. 46, 225-340. https://doi. org/10.1016/S0065-2881(03)46005-7

Dan-Kishiya AS. 2013. Length-Weight Relationship and Condition Factor of Five Fish Species from a Tropical Water Supply Reservoir in Abuja, Nigeria. AJRC 1, $175-187$

Dan-Kishiya, Dwyer KS, Parrish CC, Brown JA .2003. Lipid composition of yellow tail flounder (Limanda ferruginea) in relation to dietary lipid intake. Mar. Biol. 143, 659-667. https://doi.org/10.1007/s00227-003-1101-0

D-A-C̈H. 2008. Deutsche Gesellschaft für Ernährung, Österreichische Gesellschaft für Ernährung, Schweizerische Gesellschaft für Ernährungsforschung, Schweizerische Vereinigung für Ernährung: Referenzwerte für die Nährstoffzufuhr, Umschau/Braus Verlag, Frankfurt. 
EL Oudiani S, Darej C, Moujahed N. 2016. Fatty acids and amino acids contents in Scomber scombrus fillets from the South East of Tunisia. Afri. J. Biotech. 15, 1246-1252. https://doi.org/10.5897/AJB2016.15344

Guizani SEO, Moujahed N. 2015. Seasonal variation of Chemical and Fatty Acids Composition in Atlantic mackerel from the Tunisian Northern-East Coast. J. Food Proc. Tech. 6, 9. https://doi.org/10.4172/2157-7110.1000487

Garrido S, Rui R, Ben-Hamadou R, Cunha ME, Chícharo MA, Carl D, Lingen V. 2008. Spatio-temporal variability in fatty acid trophic biomarkers in stomach contents and muscle of Iberian sardine (Sardina pilchardus) and its relationship with spawning. Mar. Biol. 154, 1053-1065. https://doi. org/10.1007/s00227-008-0999-7

Harris WS. 1989. Fish oils and plasma lipids and lipoprotein metabolism in humans: acritical review. J. Lipid. Res. 30, 785-789.

Hunter BJ, Roberts DCK. 2000. Potencial Impact of the Fat Composition of Farmed Fish on Human Health. Nut. Res. 20, 1047-1058. https://doi.org/10.1016/S0271-5317(00)00181-0

HMSO UK. 1994. Nutritional aspects of cardiovascular disease (report on health and social subject's No. 46), London: HMSO.

International Society for the Study of Fatty Acids and Lipids (June 2004). Report of the Sub-Committee on Recommendations for Intake of Polyunsaturated Fatty Acids in Healthy Adults.

Kacem M, Sellami M, Kammoun W, Frikha F, Miled N. 2011. Seasonal variations in proximate and fatty acid composition of Viscera of Sardinella aurita, Sarpa salpa, and Sepia officinalis from Tunisia. J. Aqua. Food Prod. Techn. 20, 233-246. https://doi.org/10.1080/10498850.2011.560365

Lee RF, Hagen W, Kattner G. 2006. Lipid storage in marine zooplankton. Mar. Ecol. Prog. Ser. 307, 273-306. https://doi. org/10.3354/meps307273

Legrand P. 2007. Les acides gras: Structures, fonctions Apports nutritionnels conseillés. Cah. Nutr. Diét. 42, 7-12. https:// doi.org/10.1016/S0007-9960(07)91234-1

Moser HW, Moser AB. 1991. Measurement of very long fatty acids in plasma. Techniques in Diagnostic Human Biochemical Genetics, A Laboratory Manual. pp 177-191.

Orban E, Di Lena G, Nevigato T, Masci M, Casini I, Caproni R. 2011. Proximate unsaponifiable lipid and fatty acid composition fbogue (Boops boops) and horse mackerel (Trachurus trachurus) from the Italian trawl fishery. J. Food Comp. Anal. 24, 1110-1116. https://doi.org/10.1016/j.jfca.2011.03.009

Osman H, Suriah AR, Law EC. 2001. Fatty acid composition and cholesterol content of selected marine fish in Malaysian water. Food Chem. 73, 55-60. https://doi. org/10.1016/S0308-8146(00)00277-6

Özogul Y, Özogul F, Alagoz S. 2007. Fatty acid profiles and fat contents of commercially important seawater and freshwater fish species of Turkey. A comparative study. Food Chem. 103, 217-223. https://doi.org/10.1016/j.foodchem.2006.08.009

Pepin P, Koslow JA, S. Pearre Jr. 1988. Laboratory study of foraging by Atlantic mackerel, Scomber scombrus, on natural zooplankton assemblages. Can. J. Fish. Aquat. Sci. 45, 879-887. https://doi.org/10.1139/f88-106

Pirini M, Testi S, Ventrella V, Pagliarani A, Badiani A. 2010. Blue-back fish: Fatty acid profile in selected seasons and retention upon baking. Food Chem. 123, 306-314. https:// doi.org/10.1016/j.foodchem.2010.04.036

Romotowska PE, Karlsdóttir MG, Gudjónsdóttir M, Kristinsson HG, Arasona S. 2016. Seasonal and geographical variation in chemical composition and lipid stability of Atlantic mackerel (Scomber scombrus) caught in Icelandic waters. J. Food Comp. Anal. 49, 9-18. https://doi. org/10.1016/j.jfca.2016.03.005

Rioux V, Legrand P. 2001. Métabolisme et fonctions de l'acide myristique. Oléagineux. Corps. Gras. Lipides 8, 161-166. https://doi.org/10.1051/ocl.2001.0161

Rubio-Rodríguez N, Beltrán S, Jaime I, de Diego SM, Sanz MT, Carballido JR. 2010. Production of omega-3 polyunsaturated fatty acid concentrates. Inno. Food Sci. Emer. Tech. 11, 1-12. https://doi.org/10.1016/j.ifset.2009.10.006

Shirai N, Terayama M, Takeda H. 2002. Effect of season on the fatty acid composition and free amino acid content of the sardine Sardinops melanostictus. Comp. Bioch. Physiol. B 131, 387-393. https://doi.org/10.1016/ S1096-4959(01)00507-3

Simopolous AP.1989. Summary of the NATO Advanced Research Workshop on Dietary w3 and w6 Fatty Acids: Biological Effects and Nutritional Essentiality. J. Nut. 119, 521-528.

Soriguer F, Serna S, Valverde E, Hernando J, Martín-Reyes A, Soriguer M, Pareja A, Tinahones F, Esteva I. 1997. Lipid, protein, and calorie content of different Atlantic and Mediterranean fish, shellfish, and molluscs commonly eaten in the south of Spain. Eur. J. Epid. 13, 451-463.

Turan Y, Kayaa Y, Erdema ME. 2011. Proximate Composition, Cholesterol, and Fatty Acid Contentf Brown Shrimp (Crangon crangon L. 1758) from Sinop Region, Black Sea. J. Aquat. Food Prod. Tech. 20, 100. https://doi.org/10.1080/ 10498850.2010 .526753

Ulbritch TLV, Southgate DAT. 1991. Coronary Heart Disease: Seven Dietary Factors. Lancet 338, 985-992. https://doi. org/10.1016/0140-6736(91)91846-M

Valfre F, Caprino F, Turchini GM. 2003. The Health Benefit of Seafood. Vet. Res. Commun. 27 (I), 507-512. https://doi. org/10.1023/B:VERC.0000014208.47984.8c

Wallace PD.1 991. Seasonal variation in fat content of mackerel (Scomber scombrus L. 1758) caught in the English Channel. Fish. Res. Tech. Report 91. 